\title{
PEMAHAMAN MASYARAKAT MENGENAI GANGGUAN JIWA DAN KETERBELAKANGAN MENTAL
}

\author{
Oleh: \\ Nadira Lubis, Hetty Krisnani, \& Muhammad Fedryansyah \\ Email: \\ nadiralubis23@gmail.com; hettykrisnani@yahoo.com; fedry_cons@yahoo.com
}

\begin{abstract}
ABSTRAK
Pemahaman masyarakat mengenai gangguan jiwa dan keterbelakangan mental sangat minim. Minimnya pengetahuan masyarakat mengenai gangguan jiwa dan keterbelakangan mental menyebabkan penderita kerap kali mendapatkan perilaku yang tidak menyenangkan dari masyarakat bahkan dari keluarga penderita sendiri. Salah satunya di negara Indonesia, perlakuan yang di dapatkan oleh penderita gangguan jiwa dan keterbelakangan seperti diskriminasi, mereka terisolasi, dikucilkan bahkan hingga dipasung, padahal penderita gangguan jiwa dan cacat mental adalah warga negara Indonesia yang berhak mendapatkan hak-hak mereka sebagai warga negara Indonesia dan sebagai seorang manusia yang dapat mengembangkan diri dan mengasah potensi-potensi yang dimilikinya. Penyakit gangguan jiwa dan keterbelakangan mental memiliki pemahaman yang berbeda akan tetapi penderita sering kali mendapatkan perlakuan yang serupa dari masyarakat maupun keluarga penderita. Gangguan jiwa merupakan suatu penyakit yang dapat menyerang seseorang kapan saja dan dimana saja dan penyakit ini dapat disembuhkan dengan mendapatkan penanganan yang tepat, sedangkan cacat mental bukanlah suatu penyakit akan tetapi cacat mental merupakan suatu keadaan yang telah dialami seseorang dari semenjak dikandungan, akan tetapi bukan berarti mereka tidak dapat mengembangkan diri sebagai manusia, penanganan sejak dini dan dengan tepat juga diperlukan oleh penderita cacat mental. Maka dari itu, peran dari masyarakat sangat dibutuhkan guna untuk membantu penderita dalam bekreasi hingga dapat mengembangkan potensi-potensi yang dimilikinya dengan cara mengetahui bagaimana harus bersikap kepada mereka dengan tidak memandang penderita sebelah mata. Peran dari seorang pekerja sosial dalam hal ini dapat membantu masyarakat dan keluarga penderita gangguan jiwa atau cacat mental sebagai educator, motivator dan sebagai konselor.
\end{abstract}

Kata Kunci : Gangguan Jiwa, Keterbelakangan Mental, Cacat Mental, Pekerja Sosial

\section{PENDAHULUAN}

Gangguan jiwa menurut Depkes RI (2000) adalah suatu perubahan pada fungsi jiwa yang menyebabkan adanya gangguan pada fungsi jiwa, yang menimbulkan penderitaan pada individu dan atau hambatan dalam melaksanakan peran sosial. Terdapat bermacam-macam gangguan jiwa dengan penderita yang kerap kali dikucilkan, mendapat perlakuan diskriminasi, di isolasi bahkan hingga di pasung. Padahal perlakuan-perlakuan tersebut tidak akan membantu penderita sama sekali bahkan dapat menjadi lebih parah. Sedangkan manusia dengan keterbelakangan mental yang berbeda dengan 
penyakit mental atau yang sering disebut dengan gangguan jiwa juga kerap kali mendapatkan perlakuan yang serupa.

Masalah gangguan jiwa yang menyebabkan menurunnya kesehatan mental ini ternyata terjadi hampir di seluruh negara di dunia. WHO (World Health Organization) yaitu suatu badan dunia PBB yang menangani masalah kesehatan dunia, memandang serius masalah kesehatan mental dengan menjadikan isu global WHO. WHO mengangkat beberapa jenis gangguan jiwa seperti Schizoprenia, Alzheimer, epilepsi, keterbelakangan mental dan ketergantungan alkohol sebagai isu yang perlu mendapatkan perhatian lebih serius lagi. Dari hasil Riset Kesehatan Dasar (Riskesda) Indonesia 2007 menunjukkan bahwa:

"Penderita gangguan jiwa berat (psikosis) di Indonesia adalah 0.46 persen atau sejuta orang. Dari total populasi risiko 1,093,150 hanya 3.5 persen atau 38,260 yang baru terlayani di rumah sakit jiwa, rumah sakit umum, atau pusat kesehatan masyarakat dengan fasilitas memadai. Hal ini menunjukan tidak semua penderita mendapatkan hak-hak mereka sebagai seorang manusia dan warga negara di Indonesia. Penderita gangguan kejiwaan atau mental masih dianggap sebagai hal yang memalukan atau sebuah aib bagi keluarga atau kerabat yang salah satu anggota keluarga mengalami gangguan kesehatan mental atau kejiwaan. Masyarakat Indonesia beranggapan bahwa gangguan kesehatan mental atau kejiwaan tidak dapat disembuhkan sehingga bagi penderitanya layak dikucilkan".

Penderita gangguan jiwa dan keterbelakangan mental sangatlah berbeda. Gangguan jiwa disebabkan karena banyak hal salah satunya yang banyak terjadi di Indonesia karena pengalaman kehidupan yang di alami penderita sehingga mengganggu pikiran serta jiwa mereka, sedangkan pada penyandang keterbelakngan mental disebabkan karena rendahnya IQ yang membuat sikap dan perilaku mereka berbeda dengan manusia normal lainnya. Penderita gangguan jiwa dan keterbelakangan mental adalah warga negara Indonesia dan memiliki hak-hak sama seperti warga negara Indonesia lainnya. Wartawan Majalah Time, Andrea Star Reese, pernah sempat mengunjungi Indonesia dan menemukan orang di daerah pelosok Indonesia lebih memilih memasung anggota keluarganya yang mengidap penyakit mental seperti Skizofrenia ketimbang membawanya ke rumah sakit. Kendala umum bagi masyarakat Indonesia sehingga memilih memasung anggota keluarganya karena masalah akses ke perawatan; biaya pengobatan mahal dan kurangnya penyebarluasan informasi dasar.

Penderita gangguan kejiwaan atau mental masih dianggap sebagai hal yang memalukan atau sebuah aib bagi keluarga atau kerabat yang salah satu anggota keluarga mengalami gangguan kesehatan mental atau kejiwaan. Masyarakat Indonesia beranggapan bahwa gangguan kesehatan mental atau kejiwaan tidak dapat disembuhkan sehingga bagi penderitanya layak dikucilkan. Minimnya pengetahuan tentang gangguan kesehatan mental atau kejiwaan, membuat masyarakat Indonesia memberikan penilaian bahwa penderita gangguan kesehatan mental atau kejiawaan berbeda dengan para penderita sakit fisik yang dapat disembuhkan maupun sulit disembuhkan. Sehingga labelling penderita gangguan kesehatan mental atau kejiwaan adalah 'orang aneh' .

Dengan memberikan pengetahuan mengenai kesehatan mental atau kejiwaan (termasuk psikososial) kepada masyarakat maka secara bertahap stigma 'orang aneh yang harus dikucilkan' akan sedikit demi sedikit berkurang, dan bagi keluarga yang anggotanya memiliki gangguan kesehatan mental atau kejiwaan akan langsung memberikan pengobatan di tempat yang sesuai, selain itu dengan terbukanya pikiran masyarakat maka secara berkala profesi pekerja sosial dalam bidang medis khususnya akan ikut terangkat.

\section{SEBAB-SEBAB GANGGUAN JIWA DAN CACAT MENTAL}


Menurut Sigmund Freud dalam Santrock (1999) adanya gangguan tugas perkembangan pada masa anak terutama dalam hal berhubungan dengan orang lain sering menyebabkan frustasi, konflik, dan perasaan takut, respon orang tua yang mal adaptif pada anak akan meningkatkan stress, sedangkan frustasi dan rasa tidak percaya yang berlangsung terus-menerus dapat menyebabkan regresi dan withdral. Disamping hal tersebut di atas banyak faktor yang mendukung timbulnya gangguan jiwa yang merupakan perpaduan dari beberapa aspek yang saling mendukung yang meliputi Biologis, psikologis, sosial, lingkungan. Tidak seperti pada penyakit jasmaniah, sebab-sebab gangguan jiwa adalah kompleks.

Pada seseorang dapat terjadi penyebab satu atau beberapa faktor dan biasanya jarang berdiri sendiri. Mengetahui sebab-sebab gangguan jiwa penting untuk mencegah dan mengobatinya. Umumnya sebab-sebab gangguan jiwa menurut Santrock (1999) dibedakan atas jasmaniah/biologic seperti halnya, keturunan, jasmaniah seperti kegemukan yang cenderung menderita psikosa manik depresi dan dapat pula menjadi skizofernia, tempramen karena orang yang terlalu peka/ sensitif, penyakit dan cedera tubuh.

Selain karena jasmaniah/biologic, gangguan jiwa dapat pula terjadi karena psikologik seperti pengalaman frustasi, kegagalan dan keberhasilan yang dialami akan mewarnai sikap, kebiasaan dan sifatnya dikemudian hari. Hidup seorang manusia dapat dibagi atas 7 masa dan pada keadaan tertentu dapat mendukung terjadinya gangguan jiwa.

Gangguan jiwa dapat pula terjadi karena Sosio Kultural yaitu, kebudayaan secara teknis adalah ide atau tingkah laku yang dapat dilihat maupun yang tidak terlihat. Faktor budaya bukan merupakan penyebab langsung menimbulkan gangguan jiwa, biasanya terbatas menentukan "warna" gejala-gejala. Di samping mempengaruhi pertumbuhan dan perkembangan kepribadian seseorang misalnya melalui aturan-aturan kebiasaan yang berlaku dalam kebudayaan tersebut.

Pada keterbelakangan mental memiliki bermacam-macam penyebab seperti karena keturunan atau gen dari orang tua, pola makan sang Ibu pada masa kehamilan, pola hidup sang ibu ketika masa kehamilan dan umur ibu pada masa kehamilan juga dapat menjadi penyebab anak terlahir dengan cacat mental. Walau penyebab antara penyakit mental dan keterbelakangan mental berbeda akan tetapi perlakuan masyarakat yang mereka terima kerap kali serupa.

\section{MACAM-MACAM GANGGUAN JIWA DAN KETERBELAKANGAN MENTAL}

Terdapat macam-macam gangguan jiwa yang dimiliki oleh beberapa penderita di dunia, menurut Rusdi (1998) adapaun macam-macam dari gangguan jiwa, yaitu:

"Gangguan jiwa organik dan simtomatik, skizofrenia, gangguan skizotipal dan gangguan waham, gangguan suasana perasaan, gangguan neurotik, gangguan somatoform, sindrom perilaku yang berhubungan dengan gangguan fisiologis dan faktor fisik, Gangguan kepribadian dan perilaku masa dewasa, retardasi mental, gangguan perkembangan psikologis, gangguan perilaku dan emosional dengan onset masa kanak dan remaja (Rusdi, 1998)”.

Walau Retardasi mental termasuk dalam macam-macam dari gangguan jiwa, akan tetapi pada kenyataannya mereka yang memiliki keterbelakangan mental memiliki perbedaan dari mereka yang memiliki gangguan jiwa. Keterbelakangan mental atau cacat mental bukanlah suatu penyakit sehingga keadaan tersebut tidak dapat dicegah, sedangkan gangguan jiwa seperti skizofrenia, gangguan skizotipal dan gangguan waham, gangguan suasana perasaan, dsb, dapat disembuhkan melalui pengobatan medis. Macam-macam gangguan jiwa juga memiliki penyebab yang berbeda, mereka yang memiliki gangguan jiwa dapat disembuhkan dengan penanganan yang tepat. 
Pada keterbelakangan mental atau cacat mental (Mental Retardation) sendiri memiliki macam-macam jenis. Pengelompokan pada umumnya berdasarkan pada taraf intelegensinya, yang terdiri dari terbelakang ringan, sedang dan berat. Pengelompokan seperti ini sebenarnya bersifat artificial karena ketiga kelompok di atas tidak dibatasi oleh garis demargasi yang tajam. Gradasi dari satu level ke level berikutnya bersifat kontinyu. Kemampuan inteligensi anak cacat mental kebanyakan diukur dengan tes Stanford Binet dan Skala Weschler (WISC), yaitu, Cacat mental ringan disebut juga debil. Kelompok ini memiliki IQ antara 68-52 menurut Binet, sedangkan menurut Skala Weschler (WISC) memiliki IQ 69-55. Mereka masih dapat belajar membaca, menulis, dan berhitung sederhana. Namun pada umumnya anak cacat mental ringan tidak mampu melakukan penyesuaian social secara independen dan anak ini tidak mengalami gangguan fisik. Mereka secara fisik tampak seperti anak normal pada umumnya. Oleh karena itu agak sukar membedakan secara fisik antara anak cacat mental dengan anak normal.

Anak cacat mental sedang disebut juga imbesil. Kelompok ini memiliki IQ 51-36 berdasarkan skala Binet sedangkan menurut Skala Wsechler memiliki IQ 54- 40. Anak cacat mental sedang masih memperoleh kecakapan komunikasi selama masa anak usia dini. Walaupun agak lambat. Anak dapat mengurus atau merawat diri sendiri dengan pelatihan yang intensif. Mereka dapat memperoleh manfaat latihan kecakapan sosial dan pekerjaan namun tidak dapat menguasai kemampuan akademik seperti; membaca, menulis, dan berhitung. Akan tetapi mereka masih dapat bepergian di lingkungan yang sudah dikenalnya.

Kelompok anak cacat mental berat disebut juga idiot. Kelompok ini dapat dibedakan lagi antara anak cacat mental berat dan sangat berat. Cacat mental berat (severe) memiliki IQ antara 3220menurut skala Binet dan antara 39-25 menurut Skala Wechsler (WISC) Anak cacat mental sangat berat (profound) memiliki IQ dibawah 19 menurut Skala Binet dan IQ dibawah 24 menurut skala Wechsler (WISC). Anak cacat mental berat memerlukan bantuan perawatan secara total dalam hal berpakaian, mandi, makan, dll. Hampir semua anak cacat mental berat dan sangat berat menyandang cacat ganda. Umpamanya sebagai tambahan cacat mental tersebut si anak lumpuh (karena cacat otak) , tuli atau cacat lainnya.

\section{FENOMENA DI INDONESIA}

Gangguan jiwa dapat mengenai setiap orang, tanpa mengenal umur, ras, agama, maupun status sosial-ekonomi. Gangguan jiwa bukan disebabkan oleh kelemahan pribadi. Di masyarakat banyak beredar kepercayaan atau mitos yang salah mengenai gangguan jiwa, ada yang percaya bahwa gangguan jiwa disebabkan oleh gangguan roh jahat, ada yang menuduh bahwa itu akibat guna-guna, karena kutukan atau hukuman atas dosanya. Kepercayaan yang salah ini hanya akan merugikan penderita dan keluarganya karena pengidap gangguan jiwa tidak mendapat pengobatan secara cepat dan tepat.

Orang dengan keterbelakangan mental atau cacat mental berbeda penanganan dengan mereka yang mederita sakit mental. Cacat mental bukanlah suatu penyakit, mereka adalah suatu keadaan yang tidak dapat dicegah. Akan tetapi mereka dapat belajar sehingga mampu untuk menjalankan hidup. Pembelajaran yang mereka dapat perlu dilakukan secara terus-menerus dan berkelanjutan. Orang dengan gangguan jiwa dan keterbelakangan mental kerap kali mendapatka perlakuan yang sama dan dianggap sebagi sebuah musibah atau bencana. Hal ini terjadi dikarenakan kurangnya pemahaman dari masyarakat sendiri mengenai gangguan jiwa dan cacat mental.

Di zaman ponsel pintar seperti sekarang, realitanya masih banyak masyarakat Indonesia yang masih awam tentang gangguan jiwa dan cacat mental. Masih lebih banyak orang yang mengabaikan pentingnya menimbang, mengupayakan dan mempertahankan kesehatan jiwa dan mental dibandingkan dengan kesehatan fisik. Sebagian anggota masyarakat baru akan memperhatikan masalah kesehatan jiwa dan mental, hanya disaat mereka dihadapkan pada gangguan kesehatan mental dan jiwa. 
Kurangnya kesadaran dan pengetahuan masyarakat tentang orang dengan penyakit mental dan keterbelakangan mental menimbulkan perlakuan dan sikap yang salah terhadap orang yang memiliki penyakit mental dan keterbelakangan mental. Persepsi masyarakat terhadap kesehatan mental berbeda di setiap kebudayaan. Dalam suatu budaya tertentu, orang-orang secara sukarela mencari bantuan dari para profesional untuk menangani gangguan jiwanya. Sebaliknya dalam kebudayaan yang lain, gangguan jiwa cenderung diabaikan sehingga penanganan akan menjadi jelek, atau di sisi lain masyarakat kurang antusias dalam mendapatkan bantuan untuk mengatasi gangguan jiwanya. Bahkan gangguan jiwa dianggap memalukan atau membawa aib bagi keluarga. Hal kedua inilah yang biasanya terjadi dikalangan masyarakat saat ini (http://health.kompas.com/).

Pengetahuan mengenai penyakit mental dan keterbelakangan mental harus kita pahami, karena apabila kita acuh terhadap informasi dan pengetahuan ini mereka tidak dapat berkembang karena kurangnya motivasi akan menghambat perkembangan mereka dan menimbulkan ketergantungan. Pemasungan, diskriminasi dan isolasi terjadi disebabkan kurangnya pengetahuan dan informasi tentang apa itu penyakit mental dan keterbelakangan mental?. Di negara Indonesia terutama adalah negara yang masih ditemukan kasus pemasungan terhadap anak dengan penyakit mental atau cacat mental yang di lakukan oleh keluarga mereka sendiri dengan diperlakukan seperti bukan seorang manusia.

Model kesehatan di dunia barat memandang gangguan jiwa sebagai suatu hal yang harus disembuhkan. Sehingga pelayanan kesehatan jiwa cenderung berorientasi hanya pada gangguan jiwa yang menimpa orang tersebut dan sering mengabaikan aspek-aspek yang berkaitan dengan kehidupan dan kesejahteraan kliennya. Maka dari itu, di dunia barat mereka yang mengidap penyakit mental memiliki penanganan khusus tanpa mengisolasi penderita atau bahkan hingga memasung seperti yang banyak terjadi di daerah-daerah yang terdapat di Indonesia. Berbeda dengan negara barat, masyarakat Indonesia masih belum terlalu peduli terhadap penanganan dan perawatan penderita penyakit mental dan keterbelakangan mental seperti di beberapa daerah di Indonesia (Sumber: rsjlawang.com).

Beberapa kasus di Indonesia terutama di daerah-daerah terpencil kerap kali ditemukan kasus pemasungan atau kurungan terhadap mereka yang menderita penyakit mental atau keterbelakangan mental. Mereka mendapatkan perlakuan yang tidak menyenangkan karena perilaku mereka dianggap aib atau mengganggu ketenangan masyarakat setempat sehingga hak asasi manusia mereka direnggut karena pemasungan atau kurungan tersebut. Pemasungan dan kurungan merupakan salah satu tindakan yang melanggar hak asasi manusia, walau bagaimanapun mereka memiliki hak untuk dapat hidup dengan layak seperti layaknya orang normal. Perilaku tidak menyenangkan ini seperti yang telah disebutkan terjadi karena minimnya pengetahuan dan informasi bagaimana cara berkomunikasi terhadap penderita penyakit mental dan keterbelakangan mental.

Pemicu dan faktor resiko sakit jiwa bisa disebabkan karena stressor yang berlebihan dan tidak bisa ditangani dengan baik, contoh mudahnya adalah tertimpa musibah, mengidap penyakit maupun faktor sosial lainnya. Pemerintah juga membantu untuk pengobatan dan perawatan penderita gangguan sakit jiwa ini. Kementerian Kesehatan mendorong pemerintah daerah untuk meningkatkan fasilitas kesehatan jiwa. Rumah sakit jiwa di Indonesia yang dimiliki pemerintah hanya 33 buah. Sedangkan rumah sakit jiwa atau klinik-klinik penderita gangguan jiwa yang dikelola swasta berjumlah sekitar 40-an. Jumlah ini dirasa masih sangat kurang karena penderita gangguan jiwa di Indonesia masih cukup banyak. Ada sedikit perbedaan antara sakit jiwa dan gangguan jiwa. Bila gangguan jiwa adalah gangguan pikiran, perasaan atau tingkah laku sehingga menimbulkan penderitaan dan terganggunya fungsi kehidupan sehari-hari. Sedangkan sakit jiwa lebih dominan dan menjurus pada gangguan jiwa berat yang memerlukan pengobatan dan perawatan khusus pula.

\section{PENTINGNYA SIGNIFICANT OTHERS}

Kelemahan yang dimiliki anak-anak penyandang cacat mental dan penyakit mental menyebabkan mereka membutuhkan bantuan yang lebih banyak dan intensif dari orang-orang sekitar 
dalam menjalani kehidupannya. Masalah utama bagi perkembangan anak penyandang cacat mental adalah ketidakmampuan mereka dalam mempelajari situasi yang terjadi di sekitar mereka. Oleh karena itu, Seseorang dengan gangguan mental dengan segera membutuhkan perawatan atau kontrol, seseorang tersebut haruslah di bawa ke tempat yang aman. Orang harus diperiksa oleh dokter dan diwawancarai oleh seorang praktisi kesehatan mental disetujui (sebelumnya seorang pekerja sosialah yang disetujui terlebih dahulu). Di masing-masing level dari pemasungan, isolasi dan diskriminasi memiliki isu perkembangan koresponden yang merefleksikan fungsi sosial. Bagian selanjutnya yang mendiskusikan tantangan yang dihadapi oleh individu-individu pada berbagai macam level yang menekankan orang dengan disabilitas mental. Oleh karena itu, keadaan lingkungan sosial haruslah mendukung perkembangan pada orang pengidap penyakit mental dan keterbelakangan mental. Lingkungan sosial sangat berperan terhadap aktifitas sehari-hari yang di jalani oleh penderita, melalui lingkungan sosial mereka dapat hidup selayaknya orang normal.

Pentingnya pendidikan yang baik untuk anak penyakit mental dan anak dengan keterbelakangan mental, karena perkembangan pada mereka memerlukan perhatian yang khusus. Walau anak dengan keterbelakangan mental memiliki IQ di bawah rata-rata, akan tetapi buka berarti mereka tidak memiliki potensi dalam dirinya. karena anak penderita down syndrome juga dapat mengukir prestasi yang dapat meraih penghargaan dari kejuaraan-kejuaraan salah satunya adalah Stephanie Handojo (21) yang telah tampil sebagai peraih emas cabang renang di World Special Olympics di Athena, Yunani, pada Juli 2011 (Republika, 2012:04). Sama halnya dengan pengidap keterbelakangan mental, penderita penyakit mental pun memiliki potensi-potenti yang dapat dikembangkan apabila didukung oleh keluarga, masyarakat atau lingkungan sosial mereka.

Penderita gangguan jiwa tidak mungkin mampu mengatasi masalah kejiwaanya sendiri. Individu tersebut membutuhkan peran orang lain di sekitarnya, khususnya keluarganya. Peran keluarga dalam kesembuhan dan kekambuhan penderita gangguan jiwa sangat penting, karena keluargalah orang yang paling dekat dengan penderita gangguan jiwa.Pencegahan kekambuhan atau mempertahankan penderita gangguan jiwa di lingkungan keluarga dapat terlaksana dengan persiapan pulang yang adekuat serta mobilisasi fasilitas pelayanan kesehatan yang ada di masyarakat khususnya peran serta keluarga.

Tersedianya berbagai macam treatment dan terapi seharusnya dapat menjadi solusi atau jawaban bagi masyarakat yang mempertanyakan dan meragukan akan kesembuhan bagi para penderita gangguan kesehatan mental atau kejiwaan. Banyak terapi pada zaman sekarang yang banyak di lakukan untuk menyembuhkan orang dengan penyakit mental untuk orang dengan keterbelakangan mental pendidikan menjadi kunci utama mereka untuk berkembang dan menggali potensinya.

Pengetahuan dan informasi mengenai penyakit mental dan keterbelakangan mental harus diketahui oleh seluruh masyarakat Indonesia agar tidak kembali lagi terjadi perilaku-perilaku yang melanggar hak asasi manusia pada penderita. Mulai dari penyebab mereka menderita gangguan jiwa atau keterbelakangan mental, cara berkomunikasi dengan mereka hingga mengetahui perawatan yang tepat untuk mereka agar dapat sembuh atau dapat mengembangkan potensi yang dimilikinya.

\section{PENUTUP}

Manusia dengan Gangguan mental dan keterbelakangan mental bukanlah suatu kutukan dan hal yang menakutkan akan tetapi, perilaku dan tindakan mereka kerap kali melanggar nilai dan norma yang berlaku di masyarakat sehingga mereka tidak jarang mendapatkan perlakuan yang tidak menyenangkan hingga melanggar hak asasi manusia. Di Indonesia sendiri banyak kasus ditemukan yang memprihatinkan seperti kasus pemasungan dan pengurungan terhadap mereka yang menderita gangguan mental atau cacat mental. 
Mereka dengan penderita gangguan mental dan keterbelakangan mental adalah manusia yang berhak mendapatkan hak untuk hidup dengan layak seperti manusia normal pada umumnya. Pendidikan, perawatan, sosialisasi dengan lingkungan sekitar juga berhak mereka dapatkan sebagai seorang manusia, akan tetapi karena minimnya pengetahuan dan informasi pada masyarakan mengenai penyakit mental dan keterbelakangan mentalah yang merenggut hak-hak asasi mereka sebagai manusia dan warga negara Indonesia.

Maka dari itu, pengetahuan dan informasi mengenai penyakit mental dan keterbelakangan mental sangat penting di ketahui dan di pahami oleh seluruh masyarakat khususnya masyarakat Indonesia. Perhatian yang khusus dan perawatan terhadap mereka dapat membuat mereka mampu mengembangkan potensi-potensi yang mereka miliki bahkan tidak jarang diantara mereka yang dapat berprestasi hingga membanggakan keluarga, masyarakat dan bangsa Indonesia.

Dengan bertambahnya pengetahuan dan informasi mengenai penderita penyakit mental dan gangguan mental diharapkan dapat menambahkan rasa kepedulian masyarakat Indonesia terhadap hak-hak mereka sebagai penderita. Motivasi adalah keadaan psikologis yang merangsang dan memberi arah terhadap aktivitas manusia. Dialah kekuatan yang menggerakkan dan mendorong aktivitas seseorang. Motivasi menjadi salah satu kunci sebagai alat penyembuhan terhadap mereka yang menderita gangguan jiwa.

\section{DAFTAR RUJUKAN}

Wibhawa,Budhi,dkk. 2010. Dasar-dasar Pekerjaan Sosial. Bandung. Widya Padjadjaran

Koplan, Tony. 2009. Children and Adolescent with Mental Helath Problems. The Royal College of Psychiatrists: London.

Maslim, Rusdi. 1998. Buku Saku Diagnosis Gangguan Jiwa. Jakarta

Semrud-Clikeman, Margaret. 2007. Social Competence in Children. Springer Science+Business Media, LCC: USA.

Prinz, Ronald J. (1991). “Advances in Behavioral Assessment of Children and Families”. Volume 5. London: Jessica Kingsley Publishers.

Hendriani, Wiwin, dkk. (2006). "Penerimaan Keluarga terhadap Individu yang Mengalami Keterbelakangan Mental". INSAN Vol. 8 No.2 Agustus 2006.

Republika. 2012. Penderita Down Syndrome Mengukir Prestasi.

Undang-Undang Republik Indonesia Tentang Kesehatan Jiwa No.3 Tahun 1996

www.terapicalistung.com. Anak Keterbelakangan Mental. Diunduh Pada Tanggal 16 September 2014. Pukul: 07.44 WIB.

Faperta.ugm.ac.id. Kesehatan Jiwa. Diunduh Pada Tanggal 22 Oktober 2014. Pukul: 20.46 WIB.

Psikologi.ug.ac.id. Aksi Hari Kesehatan Jiwa Sedunia. Diunduh Pada Tanggal 30 Oktober 2014 Pukul17.05 WIB.

http://health.kompas.com. Gangguan Jiwa Masih Diabaikan. Diunduh Pada Tanggal 13 Desember 2014 Pukul 17.14 WIB

rsjlawang.com. Pengaruh Kebudayaan Terhadap Pemahaman dan Pelayanan Masyarakat. Diunduh Pada Tanggal 13 Desember 2014 Pukul 16.50 WIB 